[農化 第 36 巻，第 2 号, p. $138 \sim 140,1962$ ]

\author{
血清，尿，食品中のシスチン定量用合成培地 \\ 条件の設定について(第 4 報)* \\ 味噌についての検討

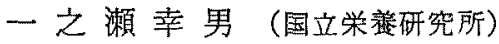 \\ 昭和 36 年 7 月 11 日受理
}

緒 言

L. M. Henderson, E. E. Snell(1), H. E. Sauberlich et al. (2), 田村学造等( ${ }^{(3)}$ の多年の努力により，シスチン 以外はアミノ酸定量用の合成培地が設定される段階汇きた。

シスチン定量用合成培地の問題点は，(1) 標漼曲線が低いこと，(2) 回収率の不良の 2 点である．著者は次の よ弓な榆索過程を経て，シスチン定量用合成培地を設定してみた，出発点としては 1952 年田村等 ${ }^{(3)}$ が設定した 標準合成培地を採用し，検討の結果，具合の悪い個所を変更していく立場をとった。

\title{
合成培地 の検討
}

常法（15 ポンド 10 分）で減菌中，タイムスイッチのベルの故障のため，15ポンドで 29 分閒も隇菌したこと があったこの時のシスチン標準曲線は完全にねてしまったので使いるのにならなかったが，隇菌時のシスチン の破壊を予感した，検討の結果，常法隇菌（15ポンド10 分）ではシスチンの1部が破壞することを見出した.

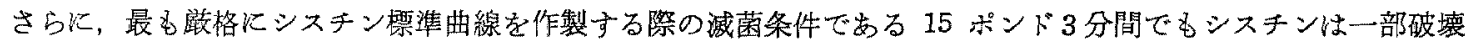
されることを見出した(第 1 報)(文，そして，シスチンの破壊によって生成する物質をペーパークロマトグラフィ

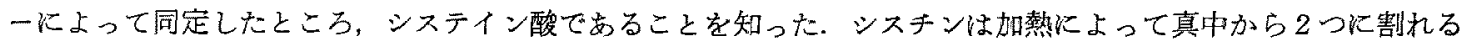
ことを察知した (第 2 報) (5).

滅菌条件を 10 ポンド 5 分間オートクレイブすることにより，シスチンの破壊は防止され，シスチンの標準曲 線は正常となったが、な蚛測定值のばらつきは改善されなかった。ここにおいて,標準合成培地中の各成分の量的 関係に過不足が安るのではないかと考光，菌体の栄盖要求を再検討し，菌体に適合した合成培地条件を検討した 結果，最も問題となるのはメチオニン量であることを知った.すなわち現在，最も広く用いられているシスチン 定量用天然培地であるランチオナイズドカゼイン培地中のメチオニン含量は低く，田村合成培地中のメチオニン 含量の約 $1 / 4$ に過ぎない，従って，田村合成培地中の過鄱のメチオニンが，高等動物に辂けるが如く 1 部シスキ

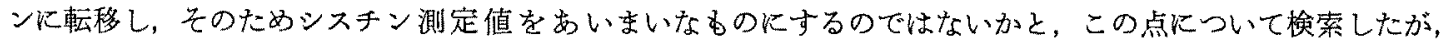
Leuc. mesenteroides p-60では, メチオニンからシスチンへの転移は䜑められなかった.

ランチオナイズドカゼイン培地には特に乳酸菌の発育因子である葉酸が添加されているので, 菌が最大增殖す る葉酸条件を検討し， $1 \mathrm{cc}$ あたり $0.3 r$ 添加が適当であることを知った.

以上の検索結果から，隇菌采件を 10 ポンド 5 分間オートクレイブすることとし，田村合成培地中のメチオ二

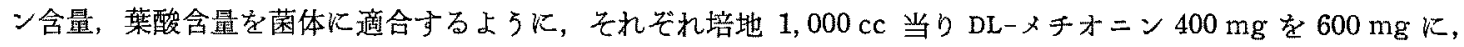
葉酸 $200 \curlyvee$ を $300 \gamma$ に变更してみた。この試作培地条件に上って，血清，㽷，牛肉，脙肉，鷄肉，鯨肉について 検討したところ，回収率が殆んど $100 \%$ の良好な成績を得た（第 3 報)(6).

今回は味噌に本試作培地条件を適用し，本法が使えるか否かを検討してみた。味噌は田村等がシスチンの標準 曲線が低いこと及び回収率が悪いことを発見した材料である。

\section{実 験方 法}

（1）使用菌株：シスチンに対して最も敏感とされている Leuc. mesenteroides P-60を用いた。

(2) 培養条件： $37^{\circ}$ で 72 時間培聇した.

* A Minimal Medium for Analysis of Cystein in Serum, Urine and Foods. Part IV. Studies on "Miso".

By Yukio ICHINOSE (The National Institute of Nutrition) 


\begin{tabular}{|c|c|c|c|c|}
\hline 分 & 称 & 使用量 & $\mathrm{pH}$ 調整 & 理 \\
\hline $\begin{array}{l}\text { シスチン定量 } \\
\text { の時のみる }\end{array}$ & $\begin{array}{l}\text { シスチン欠アミノ酸混液原液 } \\
\text { 葉 酸 原 液 }(30 \mathrm{r} / \mathrm{cc})\end{array}$ & $\begin{array}{c}40 \mathrm{cc} \\
1\end{array}$ & & 水（pH 6.8）を加觉全量 \\
\hline $\begin{array}{l}\text { 他のアミ>酸 } \\
\text { 定量の時之共 } \\
\text { 通する部分 }\end{array}$ & 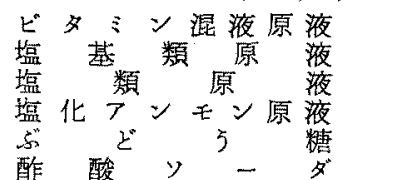 & $\begin{array}{l}4 \\
20 \\
4 \\
0.4 \\
4 \mathrm{~g} \\
4 \mathrm{~g}\end{array}$ & 6.8 K調整 & 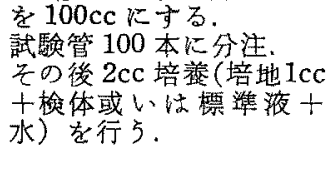 \\
\hline
\end{tabular}

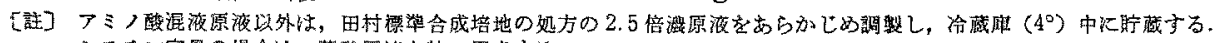

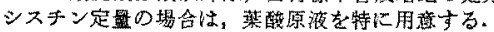

第 1 表（2）シスチン欠アミノ酸混液原液の調整法

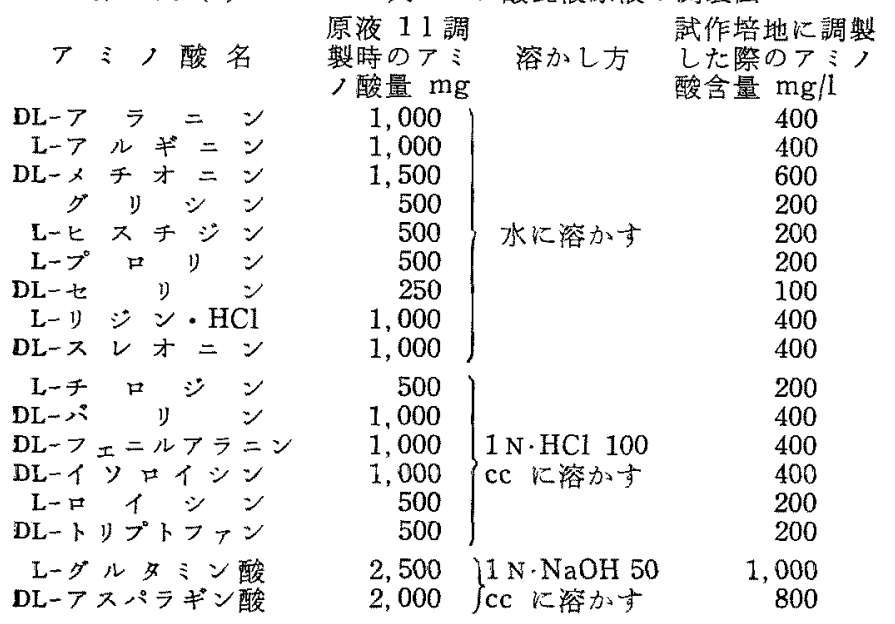

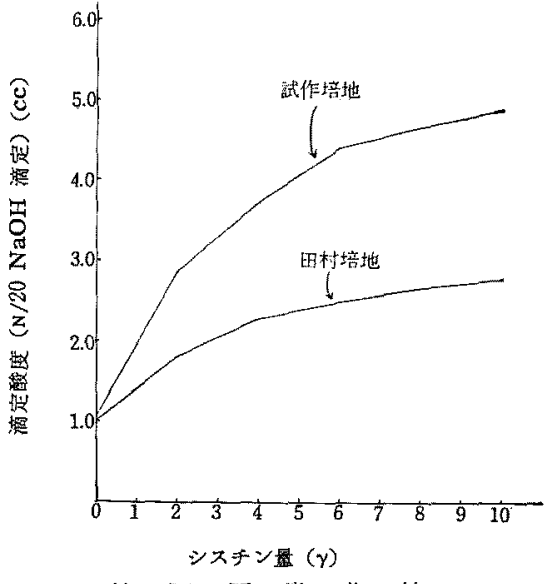

第 1 図整 準 曲 線

第 2 表味に嘼にける検討

明村合成培地

検体检 体 名 $\mathrm{N} \%$

\begin{tabular}{|c|c|c|}
\hline & 日光こ5ビ味噌 & \\
\hline 2 & 信 州桇 照 & \\
\hline & 仙 台 & \\
\hline & 津 & \\
\hline & 信州こ5し味噌 & \\
\hline 6 & 渡味 & \\
\hline & 後 味 & \\
\hline & 古屋昧 & \\
\hline
\end{tabular}

名古屋味 噌 6.89
脱脂物 0.5 脱脂物 $0.5 \mathrm{mg}$ $\mathrm{mg}$ あたり サシスチン $2 \gamma$ 回取率

$\begin{array}{lll}1.8 \gamma & 4.2 \gamma & 120 \% \\ 1.6 & 4.1 & 125 \\ 1.5 & 3.8 & 115 \\ 1.4 & 4.1 & 135 \\ 1.8 & 4.5 & 135 \\ 2.2 & 4.9 & 135 \\ 1.9 & 4.8 & 145 \\ 2.7 & 5.5 & 140\end{array}$

\begin{tabular}{|c|c|c|}
\hline 脱脂物 0.5 & 脱脂物 $0.5 \mathrm{mg}$ & 回収 \\
\hline mg あたり & $+シ ス チ ン 2 \gamma$ & \\
\hline $3.9 \gamma$ & 5.97 & $100 \%$ \\
\hline 3.5 & 5.4 & 95 \\
\hline 2.9 & 4.9 & 100 \\
\hline 3.0 & 5.0 & 100 \\
\hline 2.5 & 4.4 & 95 \\
\hline 2.7 & 4.6 & 95 \\
\hline 2.7 & 4.7 & 100 \\
\hline 3.5 & 5.5 & 100 \\
\hline
\end{tabular}

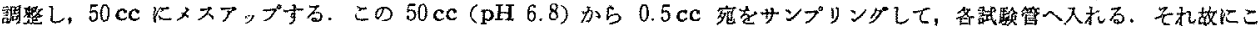
の $0.5 \mathrm{cc}$ K対する判定值は, 脱脂物にして $0.5 \mathrm{mg}$ むたりの值になる.

(3) 培地：第 1 表纪記す.

（4）接種菌数：常法通り前培荃，無菌的遠心分離後，隇菌生理的食塩水中に㦟濁し，乾燥減菌した注射筒 より1滴 $(0.01 \mathrm{cc})$ を滴下接種した. $0.01 \mathrm{cc}$ 中の総菌数は $15 \times 10^{6} \sim 17 \times 10^{6}$ で, 生菌数は $13 \times 10^{6} \sim 15 \times 10^{6}$ であった.

（5）検体： 市肘の8 種頑の味噌をエーテルで脱脂し，エタノールで脱水して用いた。

\section{実験 結 果}

（1）田村等が指摘せる如く，田村合成培地ではシスチンの標準曲線は低く，かつ回収率が思わしくなかった (第 1 図，第 2 表).

（2）本試作培地条件では，シスチンの分解は防がれ，その標準曲線は正常(リシン，ィチオニン程度の角度) の角度を示し, 回収率も $100 \%$ 前後とい5良好な成績を收めた。 


\section{考 察}

田村合成培地でのシスチンの回収率が一様に高くなる原因を次のよ5に考点る。すなわら，標準曲線用の試験 管の中にはシスチン標準液と 17 種純品アミノ酸が入っているだけなので，加熱によってシスチン摽準液は壤れ やすいが，検体用の試驗管の中にはシスキン添加液のほかに，検体の加水分解物（フミノ酸類，1ミノ酸類，て の他種々の窒素化合物) が入っているので, シスチンは破壊から比較的保護されるのではなからうか。破蕒度の 大きいシスチン摽準曲線で破壊度が若干少い検体添加シスキン量をグラフ上から読むので, 回収量が高く出るの ではないかと推定される.

酸化カゼインの加水分解物であるランチオナイズカゼイン天然培地使用時のシスチン標準曲線が比較的ねない のも、同じょうな理由に基つくるのと思われる。

要

約

田村合成培地を一部変更（メチオニン，葉酸含量を变更）し，隇菌条件を 10 ポンド5分オートクレイブにす ることにより，味㬝の中のシスチン量が良好な回収率をるって測定できることを知った. かくて合成培地によっ て 18 種アミノ酸が定量できる段階に到達した。

終りに御指導を戴いた所長有本邦太郎先生，栄盖化学部長速水決先生に深く感謝致します。な怙本研究は昭和 34 年 7 月 18 日, 日本農芸化学会関東支部会で講演した。

(1) L. M. Henderson, E. E. Snell : J. Biol. Chem., 172, 15 (1948).

(2) H. E. Sauberlich et al. : ibid., 177, 533 (1949).

（3）田村学造, 角田俊直, 桐村二郎, 宮沢 滋：

本誌，26，465 (1952).

（4）一之瀬男：栄羕学雑誌，18，296 (1960).

（5）一之瀬幸男：同上，18，299 (1960).

（6）一之瀬幸男：同上，18，301 (1960). 